\title{
Secondary production of an intertidal mussel bed community related to its storage and turnover compartments
}

\author{
Harald Asmus \\ Biologische Anstalt Helgoland, Litoralstation List, D-2282 List, Sylt, Federal Republic of Germany
}

\begin{abstract}
Macrofaunal biomass and production were studied at 6 sites on an intertidal mussel bed in the northern Wadden Sea near the island of Sylt (North Sea) in 1984. Mean biomass of the community was about 25 times higher (1243 $\mathrm{g} \mathrm{AFDW}^{-2}$ ) than in other communities of the Wadden Sea. Of this biomass, $97 \%$ was represented by the mussel Mytilus edulis L. Although associated fauna had a share of only $3 \%$, their absolute biomass of $35 \mathrm{~g} \mathrm{AFDW} \mathrm{m}^{-2}$ is in the range reported for other intertidal communities of the Wadden Sea. Annual production of the macrofaunal community $468 \mathrm{~g} \mathrm{AFDW} \mathrm{m}^{-2}$ $\mathrm{yr}^{-1}$ ) was dominated by mussels (436 $\mathrm{g}$ AFDW m $\mathrm{m}^{-2} \mathrm{yr}^{-1}$ ). P/B-ratio was very low for the total community (0.36). Annual production of associated macrofauna was much lower ( $31 \mathrm{~g} \mathrm{AFDW} \mathrm{m}^{-2} \mathrm{yr}^{-1}$ ) but the P/Bratio (0.89) indicates a higher tumover rate. Suspension feeders had the greatest share in secondary production, followed by grazers. Predators and detritus feeders were of lesser importance. Biomass and production of individuals of higher mass dominated overwhelmingly over smaller size groups. The main productive potential of the community is formed by the larger size classes. These are of only minimal importance for predation. Therefore the community can be divided into 2 functional compartments: (1) a storage compartment with a high productive potential leading to further increase in biomass or being spent for metabolic and reproductive requirements; and (2) a turnover compartment. with relatively low biomass and production but higher turnover. The production of the turnover compartment is available to most predators.
\end{abstract}

\section{INTRODUCTION}

Although biomass and production values have been reported for mussel populations from several coastal regions (Milne \& Dunnet 1972, Dare 1976, Bayne \& Worall 1980, Kautsky 1981, Briggs 1982, Rodhouse et al. 1985, Craeymeersch et al. 1986. Smaal et al. 1986), up to now no attempt has been made to calculate the secondary production of a total mussel bed community. Such an investigation is necessary in order to estimate the amount of energy made available by community members to higher trophic levels. In this study the secondary production was calculated for each size class of each species of benthic macrofauna of an intertidal mussel bed community. The size spectra of prey preferred by predators are known (Voous 1962, Ebling et al. 1964, Milne \& Dunnet 1972, Swennen 1976) and thus the part of production utilized by predators could be estimated.

The main food and energy source of predators in beds of blue mussels Mytilus edulis L. is composed of juvenile mussels and other associated species. This part of the community is characterized by high P/B ratios and thus relatively rapid turnover. Juvenile mussels and associated fauna are combined in the 'turnover compartment' in this investigation. The production of the other part of the community consisting of larger mussels is subject to only little predation pressure. In addition larger mussels have low $P / B$ ratios. Consequently this part of the total production will be stored as biomass. A 'storage compartment', composed of larger mussels, is therefore proposed.

The division into 2 compartments revealed that storage of mussel bed production exceeds energy flow to higher trophic levels. This represents a fundamental difference to most benthic macrofauna communities of intertidal waters. Nevertheless the production in mussel beds made available to predators is of the same order of magnitude as in other Wadden Sea communities. 


\section{MATERIALS AND METHODS}

Study site. This investigation was carried out in the northern Wadden Sea (North Sea) near the island of Sylt from December 1983 until November 1984 (Fig. 1). The investugated mussel ground in the outer Konigshafen borders the tidal flats at the low water mark (Fig. 2). In this area, mussel beds of varying size and tide pools build up a dense mosaic. The mussel beds are covered with water for about $10 \mathrm{~h}$ withun a tidal cycle. The tıdal range in this area is $1.80 \mathrm{~m}$, which is also the mean water depth at the study site during high water.

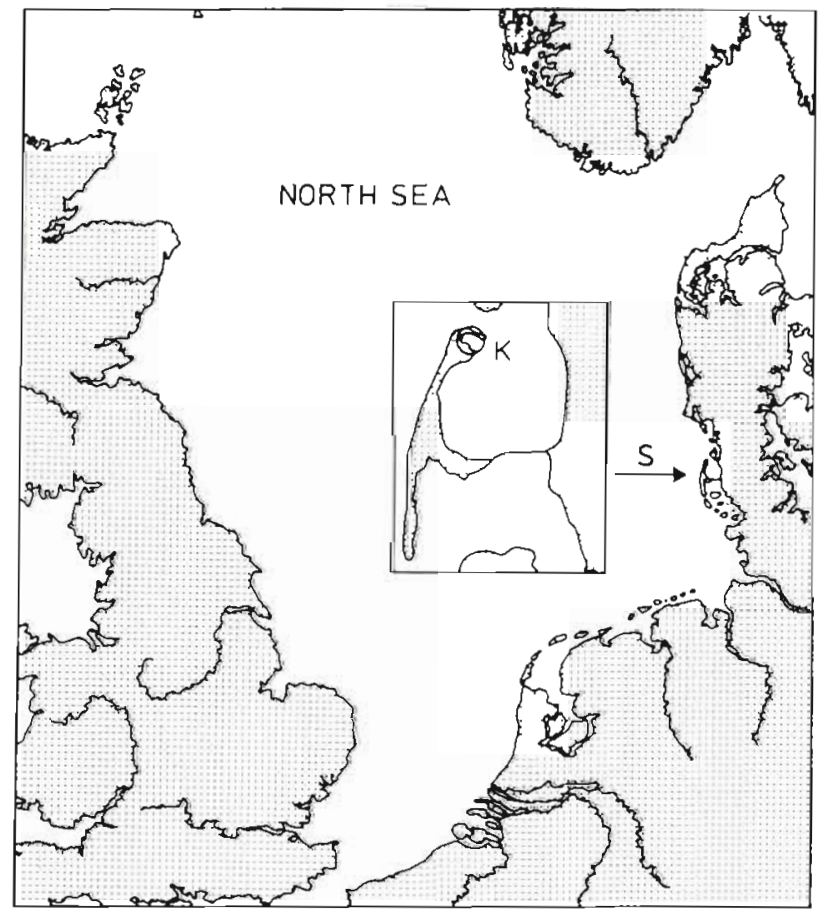

Fig 1. The Kongshafen area $(\mathrm{K})$ at the northern part of the island of Sylt (S) in the northern Wadden Sea (North Sea)

Sampling. Macrofaunal biomass and production were studied at 6 sites on the mussel ground (Fig. 2). Every month 5 sediment cores of $100 \mathrm{~cm}^{2}$ and $30 \mathrm{~cm}$ depth were taken from each site. After separatıng the macrofauna living on the sedıment surface, all samples were sieved $(0.5 \mathrm{~mm}$ mesh size). In each sample, shell length of mussels Mythlus edulis, shell height of periwinkles Littorina littorea, and shell diameter of barnacles Semibalanus balanordes and Balanus crenatus were measured in order to divide these populations into size classes. The remaining macrofauna populations showed a narrow size range, so that it was sufficient to determine individual weight of each spec1men found.

Separation into size classes. Separation of Mytrlus edulis shells into groups of different age is difficult

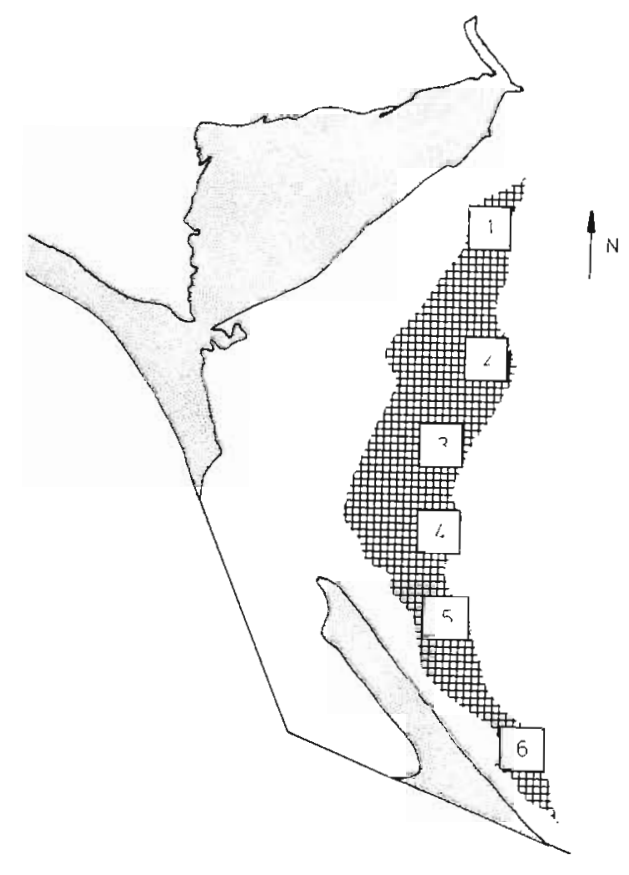

Fig. 2. The investıgation area, outer Königshafen, showing the intertıdal area covered with mussel beds (chequered). Numbers 1 to 6 mark the different study sites. Stippling indicates areas above mean high water level. Dotted line represents mean low water level

because of the lack of clear annual rings. However this problem was overcome by means of length frequency curves, in which different size classes could be distingurshed. Fig. 3A shows examples for $M$. edulis at the beginning, middle and end of the studied growing season. Three maxima could be distinguished in the range above $30 \mathrm{~mm}$. Thus this range was divided into 3 size classes (Fig. 3A, Table 1A). Below $30 \mathrm{~mm}$, another 3 different size classes could be differentiated. Young mussels first appeared in June and formed an additional size group. The boundaries between the different size classes moved upwards with growth in shell length (Table $1 \mathrm{~A}$ ), but were still recognizable at the end of the growing season.

The population of Littorina littorea showed 3 separate size classes (Fig. 3B). Young snails joined the population from June onwards, while the class of largest specimens left the mussel bed. The boundaries between the cohorts moved upwards distinctly during the growing season (Table 1B)

The population of the 2 barnacle species were separated into size classes by means of shell diameter frequency histograms (Fig. 3C, D). At the beginning of the investigation, only one size class was recognizable in both barnacle species. A spatfall of Semibalanus balanoides in spnng resulted in an additional size class. Members of the 2 size classes could be distinguished by eye. Larger specimens produced a clear white growth 

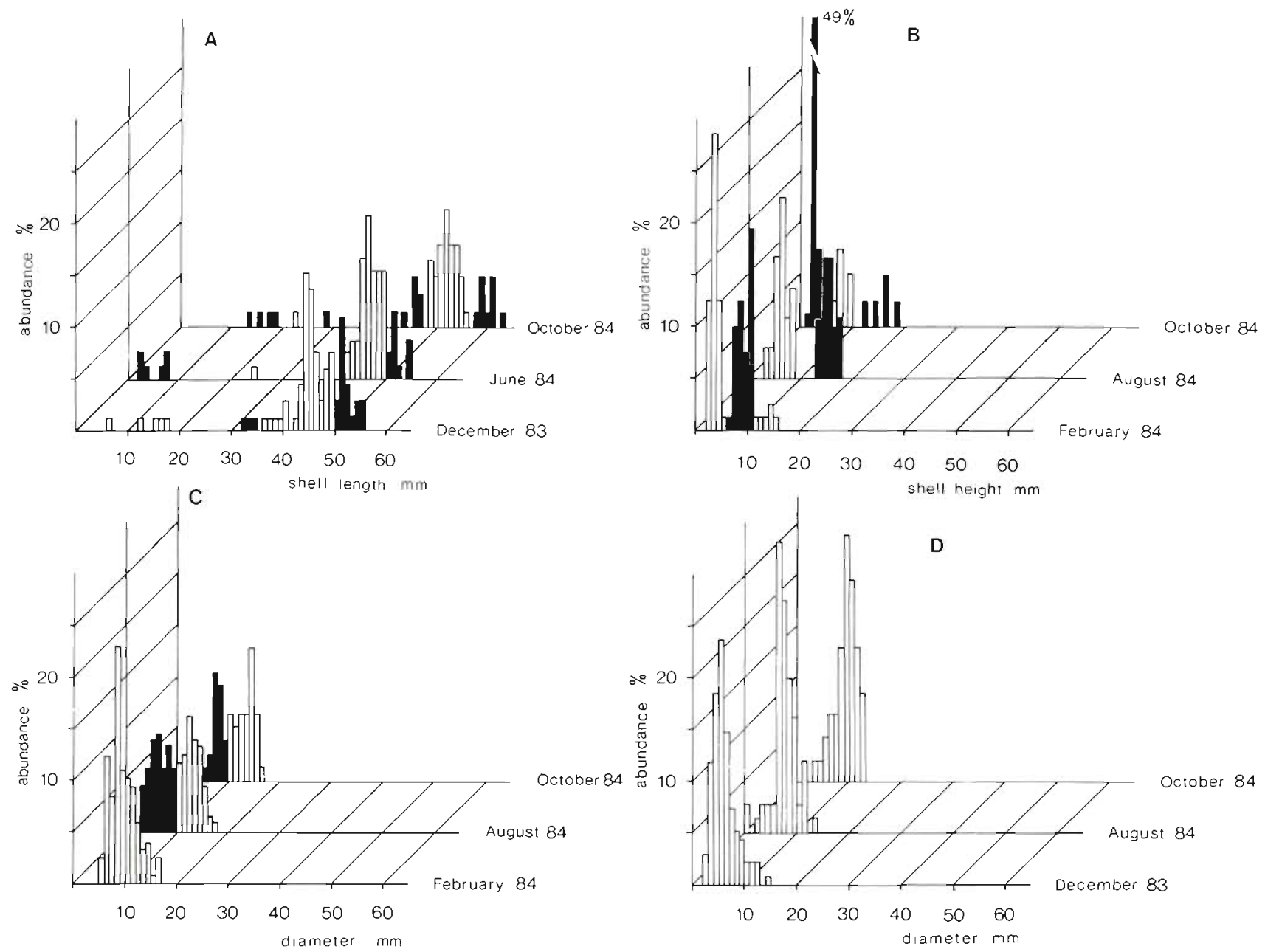

Fig. 3. Length frequency curves for different months and species. (A) Mytilus edulis at Site 1. Size classes a, c, e, g are shown black, size classes b, d, f, are white. Present at this site in December were b, d, e, f, g; in June a (newly settled), d, e, f, $g$; and in October a, b, c, e, f, g. (B) Littorina littorea at Site 6 . Size classes a and c are shown black, size classes b and d are white. Ranges of the size classes of $M$. edulis and L. littorea are presented in Table 1 (C) Semibalanus balanoides diameter frequency curve in February, August and October at Site 6. Size class of young barnacles is shown black. (D) Balanus crenatus diameter frequency curve at Site 1 in December, August and October. Only one size class is present

Table 1. (A) Mytilus edulis. Size range of size groups (a to $\mathrm{g}$ ) in $\mathrm{mm}$ during different months

\begin{tabular}{|c|c|c|c|c|c|c|c|}
\hline Month & a & b & c & $\begin{array}{l}\text { Size group } \\
\text { d }\end{array}$ & e & f & g \\
\hline Dec & - & $1-17$ & $18-22$ & $23-29$ & $30-34$ & $35-49$ & $>50$ \\
\hline Jan & - & $1-17$ & $18-22$ & $23-29$ & $30-34$ & $35-49$ & $>50$ \\
\hline Feb & - & $1-17$ & $18-22$ & $23-29$ & $30-34$ & $35-49$ & $>50$ \\
\hline Mar & - & $1-17$ & $18-22$ & $23-29$ & $30--34$ & $35-49$ & $>50$ \\
\hline Apr & - & $1-17$ & $18-22$ & $23-29$ & $30-34$ & $35-49$ & $>50$ \\
\hline May & - & $1-17$ & $18-22$ & $23-29$ & $30-34$ & $35-49$ & $>50$ \\
\hline Jun & $1-9$ & $10-19$ & $20-23$ & $24-30$ & $31-36$ & $37-49$ & $>50$ \\
\hline Jul & $1-13$ & $14-22$ & $23-26$ & $27-33$ & $34-41$ & $42-54$ & $>55$ \\
\hline Aug & $1-13$ & $14-22$ & $23-26$ & $27-33$ & $34-41$ & $42-54$ & $>55$ \\
\hline Sep & $1-15$ & $16-23$ & $24-27$ & $28-34$ & $35-41$ & $42-64$ & $>55$ \\
\hline Oct & $1-18$ & $19-26$ & $27-29$ & $30-34$ & $35-46$ & $47-56$ & $>57$ \\
\hline Nov & $1-18$ & $19-26$ & $27-29$ & $30-34$ & $35-46$ & $47-56$ & $>57$ \\
\hline
\end{tabular}


zone at the base of the calcareous plates, with older parts of the calcareous plates coloured brownish. Small barnacles were white without any noticeable growth zones. The boundary between the 2 size classes in $S$. balanoides was set at $10 \mathrm{~mm}$ diameter. The whole population of Balanus crenatus belonged to one size class.

Length-weight distribution. Length-weight relations were calculated for Mytilus edulis and Littorina littorea, and diameter-weight relations for Semibalanus balanoides and Balanus crenatus (Table 2). At each sampling, 30 to 40 individuals of each species representing the total size range of the population were prepared for determination of total ashfree dry weight to obtain a size-weight distribution. This distribution was then used to calculate the biomass of the total sampled material.

Biomass determination. Individual weights of mussels, periwinkles and barnacles were determined using the size-weight relations and summed to obtain the biomass. The biomass of other associated fauna was weighed directly. Material for biomass determinations was dried at 75 to $100^{\circ} \mathrm{C}$ for $3 \mathrm{~d}$. Ash content was determined after combustion in a furnace at $500^{\circ} \mathrm{C}$ for $24 \mathrm{~h}$. All weight and biomass data are given as ashfree dry weight.

Determination of production. For the 4 dominant species production per $\mathrm{m}^{2}$ at each site was calculated

Table 2. (A) Mytilus edulis. Length-weight distribution during different months. L: shell length $(\mathrm{cm}) ; \mathrm{W}$ ashfree dry weight

(g)

\begin{tabular}{|llc|}
\hline Month & $\begin{array}{c}\text { Regression line of } \\
\text { best fit }\end{array}$ & $\begin{array}{c}\text { Coefficient of } \\
\text { correlation }\end{array}$ \\
\hline Dec & $\mathrm{L}=4.95+1.00 \ln \mathrm{W}$ & $\mathrm{r}=0.96$ \\
Jan & $\mathrm{L}=4.96+0.92 \ln \mathrm{W}$ & $\mathrm{r}=0.96$ \\
Feb & $\mathrm{L}=4.96+0.92 \ln \mathrm{W}$ & $\mathrm{r}=0.96$ \\
Mar & $\mathrm{L}=4.91+1.00 \ln \mathrm{W}$ & $\mathrm{r}=0.97$ \\
Apr & $\mathrm{L}=4.91+1.00 \ln \mathrm{W}$ & $\mathrm{r}=0.97$ \\
May & $\mathrm{L}=4.91+1.00 \ln \mathrm{W}$ & $\mathrm{r}=0.97$ \\
Jun & $\mathrm{L}=5.28+1.80 \ln \mathrm{W}$ & $\mathrm{r}=0.99$ \\
Jul & $\mathrm{L}=4.98+1.01 \ln \mathrm{W}$ & $\mathrm{r}=0.94$ \\
Aug & $\mathrm{L}=4.98+1.01 \ln \mathrm{W}$ & $\mathrm{r}=0.94$ \\
Sep & $\mathrm{L}=4.88+0.97 \ln \mathrm{W}$ & $\mathrm{r}=0.95$ \\
Oct & $\mathrm{L}=4.88+0.97 \ln \mathrm{W}$ & $\mathrm{r}=0.95$ \\
Nov & $\mathrm{L}=4.88+0.97 \ln \mathrm{W}$ & $\mathrm{r}=0.95$ \\
& & \\
\hline
\end{tabular}

Table 1. (B) Littorina littorea. Size range of size groups (a to d) in $\mathrm{mm}$ shell height during different months

\begin{tabular}{|lcccc|}
\hline \multicolumn{5}{c}{ Size group } \\
Month & a & b & c & d \\
\hline Dec & - & $1-5$ & $6-10$ & $>11$ \\
Jan & - & $1-5$ & $6-10$ & $>11$ \\
Feb & - & $1-5$ & $6-10$ & $>11$ \\
Mar & - & $1-5$ & $6-10$ & $>11$ \\
Apr & - & $1-5$ & $6-10$ & $>11$ \\
May & - & $1-6$ & $7-11$ & $>12$ \\
Jun & - & $3-7$ & $8-11$ & $>12$ \\
Jul & - & $3-10$ & $>11$ & - \\
Aug & $1-2$ & $3-10$ & $>11$ & - \\
Sep & $1-3$ & $4-11$ & $>12$ & - \\
Oct & $1-4$ & $4-11$ & $>12$ & - \\
Nov & $1-5$ & $6-12$ & $>13$ & - \\
\hline
\end{tabular}

from changes in mean individual weight and mean abundance of size classes using the following equation (after Winberg 1971):

$$
P=\left(\bar{w}_{2}-\bar{w}_{1}\right) \times \frac{1}{2}\left(\bar{n}_{1}+\bar{n}_{2}\right)
$$

where $P=$ production for a time interval $\overline{\mathrm{w}}_{1}$ and $\overline{\mathrm{w}}_{2}=$ mean individual weights of a size class at sampling dates 1 and 2 ; and $\bar{n}_{1}$ and $\bar{n}_{2}=$ mean numerical densities of a size class at sampling dates 1 and 2 . The production of rare species with lower biomasses was calculated from their mean annual biomass and the annual P/B ratio calculated for each species after the recommendations of Banse \& Mosher (1980).

Production of each time interval was converted to daily production, which was then summed to obtain monthly production. Since the investigation started on 13 Dec 1983 monthly production was calculated from the 15th of a month to the 15th of the following month.

Length growth of mussels was determined from the monthly changes of mean shell length for each size class. As a check the length growth of marked mussels of different size classes was measured monthly. Annual growth was expressed by the growth equation of Bertalanffy $L_{t}=L_{x}\left(1-e^{-k t}\right)$, where $L_{t}$ is the shell length of a mussel at the beginning of the growing season and $L_{x}$ the maximum potential size. $L_{x}$ and $k$ were determined using a Ford Walford plot (Fig. 6). Lx results from the

Table 2. (B) Mean annual length weight distribution of dominant macrofauna. L: shell length (cm); W: total ashfree dry weight ( $\mathrm{g}$ ); D: shell diameter $(\mathrm{cm})$

\begin{tabular}{|llcrr|}
\hline Species & Regression of best fit & Coefficient of correlation & Size range (cm) & No. of individuals \\
\hline Littorina littorea & $\mathrm{L}=2.37+0.33 \ln \mathrm{W}$ & $\mathrm{r}=0.95$ & $0.10-2.20$ & 261 \\
Semibalanus balanoides & $\mathrm{D}=2.29+0.28 \ln \mathrm{W}$ & $\mathrm{r}=0.88$ & $0.19-1.87$ & 105 \\
Balanus crenatus & $\mathrm{D}=2.03+0.24 \ln \mathrm{W}$ & $\mathrm{r}=0.83$ & $0.19-1.29$ & 53 \\
\hline
\end{tabular}


intersection of the calculated regression line and the $45^{\circ}$ line. At this point $L_{t}=L_{t+1}$. The value of $k$ is calculated from the slope of the regression line of best fit, which is equal to the expression $e^{-k}$ in the Bertalanffy growth curve.

\section{RESULTS}

\section{Biomass of Mytilus edulis}

The investigated Mytilus edulis population originated from a series of dense settlements in 1979 and 1980. At this location rich mussel beds existed earlier but in the very severe winter of $1978 / 79$ they died, so that in summer 1979 only bare sand flats were left. In autumn and winter 1979/80 mussels about 6 mo old were transported by currents from sublittoral mussel beds to the study area and formed a dense secondary settlement (Reise pers. comm.).

Mean annual biomass of the Mytilus edulis community was $1243 \mathrm{~g} \mathrm{AFDW} \mathrm{m}^{-2}$. Of this, $97 \%$ (i.e. $1208 \mathrm{~g}$ AFDW $\mathrm{m}^{-2}$ ) was represented by $M$. edulis (Table 3 ). Distinct spatial differences existed between the 6 sites of the mussel bed ( 883 to $1445 \mathrm{~g} \mathrm{AFDW} \mathrm{m}^{-2}$ ). Some of the spatial variation in biomass is explained by a patchy algal cover of bladderwrack Fucus vesiculosus f. mytili (Nienburg) Nienhuis (covered mussel beds:

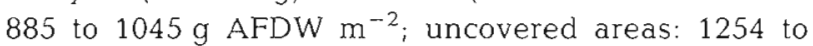
$1445 \mathrm{~g} \mathrm{AFDW} \mathrm{m}^{-2}$ ).

Biomass of the Mytilus edulis population varied only moderately over the year (Fig. 4A). From December to February the biomass remained nearly constant. Although the individual weights of the large size classes increased to relatively high values in March and April as a result of the development of spawning products, the mean individual weight of the total population rose only slightly. After spawning in April the individuals of the largest size group had minimum individual weights. The mean individual weight of the total population showed no significant changes until June. From June to September the individual weights of all size classes and thus the total biomass increased.

The abundance of Mytilus edulis was constant over the year $\left(1631 \pm 151\right.$ ind $\left.\mathrm{m}^{-2}\right)$. Only in January and April were abundances more than one standard deviation higher than the annual mean observed (1820 ind $\mathrm{m}^{-2}$ ). These dense aggregations resulted from active movements of the mussels. In October storms thinned the $M$. edulis population in the mussel beds down to 1382 ind $\mathrm{m}^{-2}$. During calmer weather in November they aggregated again.

- K. Reise, Biologische Anstalt Helgoland, Litoralstation, D2282 List, FRG
Biomass of associated macrofauna. The macrofauna of the mussel bed consisted of mobile and sessile epifauna, endofauna of the mud, and species of fishes and shrimps. Without mussels the mean annual biomass of macrofauna was $35 \mathrm{~g} \mathrm{AFDW} \mathrm{m}^{-2}$ (mean of all 6 sites). The spatial variation between the sites was low ranging from 30 to $42 \mathrm{~g} \mathrm{AFDW} \mathrm{m}^{-2}$. There was no significant correlation between the density of mussels and that of the associated fauna. Macrofaunal density was very similar in algal-covered and uncovered areas. The biomass of macrofauna associated with Mytilus edulis was composed to $89 \%$ of 18 epibenthic species and only to $11 \%$ of 22 endobenthic species.

Grazing organisms, mainly Littorina littorea, predominated with $61 \%$ of the associated faunal biomass, followed by suspension feeders $129 \%$; mainly barnacles Balanus crenatus and Semibalanus balanoides), predators $(7 \%)$ and detritus feeders $(3 \%)$. Predators occurred regularly in the mussel bed, but larger individuals leaving the mussel bed during emersion were not considered in this investigation (hermit crabs Eupagurus bernhardus, large shore crabs Carcinus maenas, brown shrimps Crangon crangon and gobies Pomatoschistus microps and $P$. minutus). However, there were several predatory species permanently present. This group was dominated by young shore crabs and the nemertines Lineus viridis and Amphiporus lactifloreus. The omnivorous species Nereis virens and $N$. diversicolor were also considered as members of the trophic group of predators.

Many species live in the sediment between the mussels. Most of these belong to trophic group of detritus feeders like the polychaetes Heteromastus filiformis, Capitella capitata, Malacocerus fuliginosus and Tharyx marioni. However biomass was dominated by the oligochaetes Tubifex sp. and Tubificoides benedenii. Detritus feeders had the highest number of species but their biomass was low.

Littorina littorea had a mean biomass of $20 \mathrm{~g}$ AFDW $\mathrm{m}^{-2}$, ranking second to Mytilus edulis (Table 3 ). The biomass decreased with some fluctuations from December to July (Fig. 4B) (highest values: 33 to $65 \mathrm{~g}$

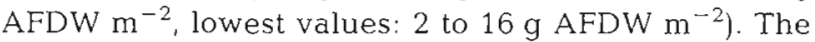
fluctuations were caused by the oldest and largest size class. Individuals of this class gathered in the mussel bed in winter. In spring many of them migrated into the adjacent flats and tide pools to graze on microalgae and macroalgal germlings. The biomass increase in August was caused by a younger generation.

Barnacles formed a large portion of the associated macrofaunal biomass (Table 3 ). Semibalanus balanoides had the greatest share in associated macrofaunal biomass $(14 \%)$ followed by Balanus crenatus $(10 \%)$ while the biomass of Elminius modestus was negligible. Barnacles had a very patchy distribution. 
Table 3. Trophic level, mean biomass, annual production and annual $\mathrm{P} / \mathrm{B}$ ratio of macrofauna in the study area. Underlined P/B ratios are calculated from biomass and production measurements. For other macrofauna production was calculated from mean biomass using the P/B ratio after Banse \& Mosher (1980). Trophic levels: s, suspension feeder; g, grazer; p, predator or omnivorous; d, detritus feeder (Total number of samples $=220$ )

\begin{tabular}{|c|c|c|c|c|}
\hline Species & $\begin{array}{l}\text { Trophic } \\
\text { level }\end{array}$ & $\begin{array}{l}\text { Mean annual biomass } \\
\left(\mathrm{g} \mathrm{AFDW}^{-2}\right)( \pm \mathrm{SD})\end{array}$ & $\begin{array}{c}\text { Annual production } \\
\left(g \text { AFDW } \mathrm{m}^{-2} \mathrm{yr}^{-1}\right)( \pm \mathrm{SD})\end{array}$ & $\begin{array}{l}\text { Annual } \\
\mathrm{P} / \mathrm{B}\end{array}$ \\
\hline \multicolumn{5}{|l|}{ Anthozoa } \\
\hline Metridium senile (L.) & $\mathrm{p}$ & $<0.01$ & 0.02 & 9.34 \\
\hline Sagartia troglodytes (Price) & $\mathrm{p}$ & $<0.01$ & $<0.01$ & 0.85 \\
\hline \multicolumn{5}{|l|}{ Nemertini } \\
\hline Amphiporus lactifloreus (Johnston) & $\mathrm{p}$ & $0.04 \pm 0.03$ & 0.08 & 1.88 \\
\hline Lineus viridis (Fabr.) Johnston & $\mathrm{p}$ & $0.02 \pm 0.01$ & 0.05 & 2.36 \\
\hline \multicolumn{5}{|l|}{ Placophora } \\
\hline Lepidochiton cinereus (L.) & $g$ & $0.11 \pm 0.05$ & 0.20 & 1.82 \\
\hline \multicolumn{5}{|l|}{ Gastropoda } \\
\hline Hydrobia ulvae (Pennant) & $\mathrm{g}$ & $<0.01$ & $<0.01$ & 6.58 \\
\hline Littorina littorea (L.) & g & $20.39 \pm 4.10$ & $9.69 \pm 4.20$ & $\underline{0.48}$ \\
\hline Littorina obtusata (L.) & g & $0.03 \pm 0.02$ & 0.09 & $\overline{2.88}$ \\
\hline Crepidula fornicata (L.) & $g$ & $<0.01$ & $<0.01$ & 0.33 \\
\hline \multicolumn{5}{|l|}{ Bivalvia } \\
\hline Mytilus edulis L. & s & $1208.47 \pm 207.42$ & $436.84 \pm 142.87$ & 0.36 \\
\hline Macoma balthica (L.) & $s, g, d$ & $0.16 \pm 0.12$ & 0.26 & 1.62 \\
\hline Mya arenaria L. & s & $1.37 \pm 0.94$ & 0.56 & 0.41 \\
\hline \multicolumn{5}{|l|}{ Polychaeta } \\
\hline Ampharete acutifrons Malmgren & d & $0.02 \pm 0.02$ & 0.05 & 2.23 \\
\hline Amphitrite figulus (Dalyell) & $g, d$ & $<0.01$ & $<0.01$ & 2.67 \\
\hline Anaitides mucosa (Oersted) & $\mathrm{p}$ & $0.08 \pm 0.13$ & 0.21 & 2.60 \\
\hline Arenicola marina (L.) & $g, d$ & $0.05 \pm 0.08$ & 0.05 & 1.09 \\
\hline Capitella capitata (Fabricius) & d & $0.38 \pm 0.16$ & 1.43 & 3.78 \\
\hline Eteone longa (Fabricius) & $\mathrm{p}$ & $<0.01$ & $<0.01$ & 4.67 \\
\hline Eumida sanguinea (Oersted) & $p$ & $<0.01$ & $<0.01$ & 4.67 \\
\hline Harmothoe sarsi Kinberg & $\mathrm{p}$ & $0.09 \pm 0.11$ & 0.11 & 1.14 \\
\hline Heteromastus filiformis (Claparède) & d & $0.34 \pm 0.29$ & 0.93 & 2.75 \\
\hline Kefersteinia cirrata (Keferstein) & $g, d$ & $<0.01$ & $<0.01$ & 6.55 \\
\hline Lepidonotus squamatus L. & $\mathrm{p}$ & $0.08 \pm 0.09$ & 0.10 & 1.19 \\
\hline Malacoceros fuliginosus (Claparède) & $g, d$ & $0.02 \pm 0.01$ & 0.12 & 6.12 \\
\hline Microphthalmus sp. & $g, d$ & $<0.01$ & $<0.01$ & 6.55 \\
\hline Nereis diversicolor O. F. Müller & $\mathrm{p}$ & $0.49 \pm 0.27$ & 0.92 & 1.88 \\
\hline Nereis virens (Sars) & $\mathrm{p}$ & $0.09 \pm 0.06$ & 0.13 & 1.54 \\
\hline Polydora ciliata (Johnston) & $g, d$ & $<0.01$ & $<0.01$ & 6.54 \\
\hline Scoloplos armiger (O. F. Müller) & d & $0.01 \pm 0.01$ & 0.04 & 2.99 \\
\hline Tharyx marioni (Saint Joseph) & $g, d$ & $0.05 \pm 0.02$ & 0.30 & 5.99 \\
\hline \multicolumn{5}{|l|}{ Clitellata } \\
\hline Tubifex sp. & $d$ & $0.31 \pm 0.09$ & 1.28 & 4.13 \\
\hline Tubificoides benedeni (Udekem) & d & $0.54 \pm 0.39$ & 2.31 & 4.28 \\
\hline \multicolumn{5}{|l|}{ Crustacea } \\
\hline Balanus crenatus Brug. & $\mathrm{s}$ & $3.57 \pm 3.21$ & $3.95 \pm 2.91$ & $\underline{1.11}$ \\
\hline Carcinus maenas (L.) & $\mathrm{p}$ & $1.52 \pm 0.78$ & 2.81 & $\overline{1.85}$ \\
\hline Elminius modestus (Darwin) & s & $<0.01$ & $<0.01$ & 4.40 \\
\hline Gammarus locusta (L.) & $\mathrm{p}$ & $0.03 \pm 0.06$ & 0.06 & 2.03 \\
\hline Jaera albifrons Leach & $g, d$ & $0.02 \pm 0.02$ & 0.14 & 7.01 \\
\hline Semibalanus balanoides (L.) & s & $4.80 \pm 7.44$ & $5.14 \pm 4.18$ & $\underline{1.08}$ \\
\hline \multicolumn{5}{|l|}{ Bryozoa } \\
\hline Membranipora membranacea (L.) & s & $<0.01$ & $<0.01$ & 4.40 \\
\hline \multicolumn{5}{|l|}{ Asteroidea } \\
\hline Asterias rubens L. & $\mathrm{p}$ & $<0.01$ & $<0.01$ & 1.23 \\
\hline \multicolumn{5}{|l|}{ Ascidiacea } \\
\hline Unknown species & s & $0.04 \pm 2.02$ & 0.14 & 3.58 \\
\hline
\end{tabular}


A

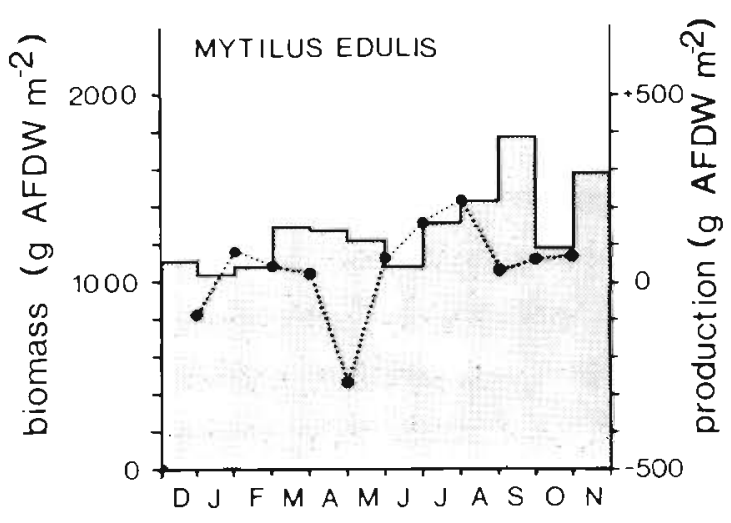

C

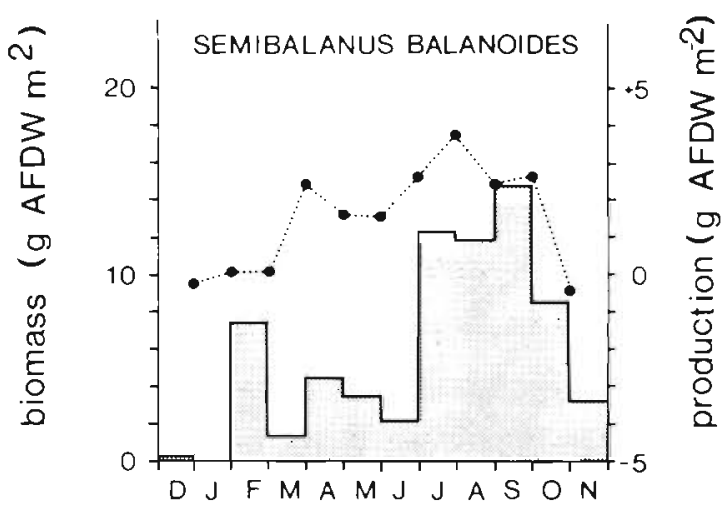

B

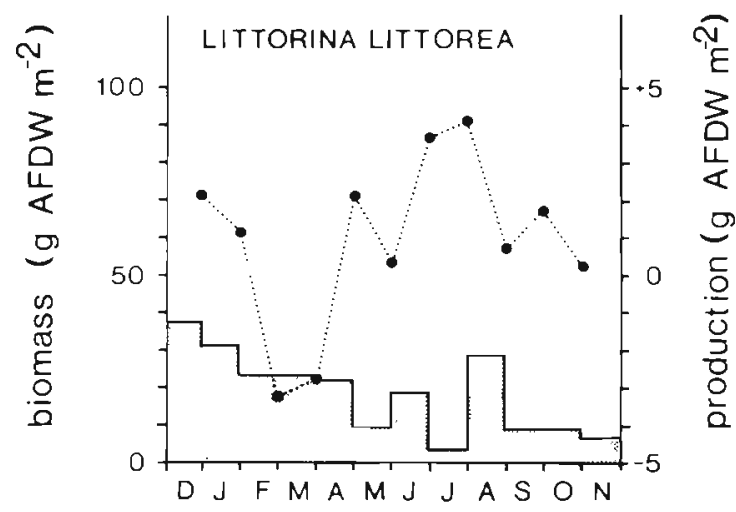

D

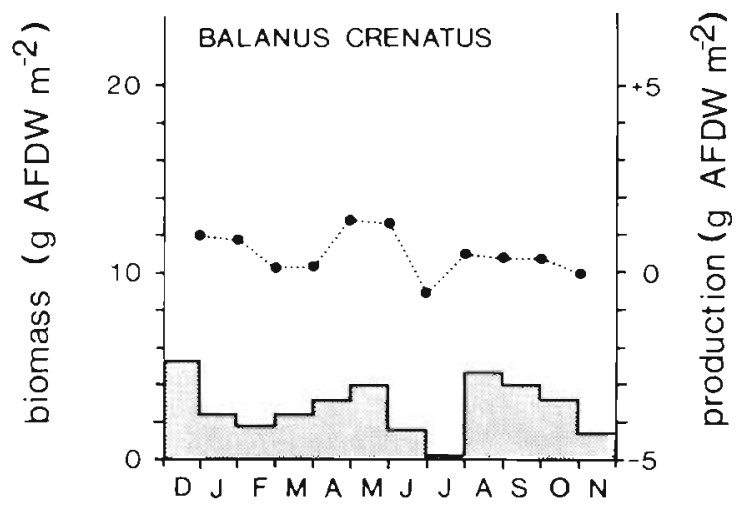

Fig. 4. Mean monthly biomass (shaded columns) and monthly production (curves) of dominant macrofauna of the mussel bed in 1984. Values represent mean of macrofaunal biomass and production taken from 30 samples each month. (A) Mytilus edulis;

(B) Littorina littorea; (C) Semibalanus balanoides; (D) Balanus crenatus

Young S. balanoides settled in April and May, but only at Sites 1, 2 and 6 was the settlement measurable. Older individuals were found at all sites in varying numbers. Algal-covered sites had a lower biomass of $S$. balanoides than uncovered sites $(0.1$ to 0.5 vs 2 to $4 \mathrm{~g}$ AFDW $\mathrm{m}^{-2}$ ). Dense aggregations of up to $20 \mathrm{~g} \mathrm{AFDW}$ $\mathrm{m}^{-2}$ were measured. Mean monthly biomass of $S$. balanoides was characterized by low values from June when older specimens dominated the population (Fig. $4 \mathrm{C})$. In the second half of the year, biomass values were high and dominated by young specimens.

In contrast to all these species there was no increase in biomass initiated by young Balanus crenatus. This species had a patchy distribution (range of mean

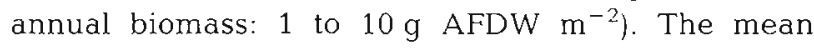
monthly biomass is presented in Fig. 4D.

\section{Production of Mytilus edulis}

Mytilus edulis accounted for $93 \%$ (corresponding to $437 \mathrm{~g} \mathrm{AFDW} \mathrm{m}^{-2} \mathrm{yr}^{-1}$ ) of total annual production of the mussel bed community (468 $\mathrm{g} \mathrm{AFDW} \mathrm{m}^{-2} \mathrm{yr}^{-1}$ ). The annual production of $M$. edulis varied from 239 to $601 \mathrm{~g}$ AFDW m ${ }^{-2} \mathrm{yr}^{-1}$ between the 6 sites (Fig. 5). Highest production was measured at Sites 5 and 6 . The mussel beds of these sites showed no algal coverage and were sheltered from intensive wave action. Production of beds covered with bladderwrack (Sites 4 and 3) was distinctly lowered. But uncovered beds (1 and 2) with higher exposure to strong wave action also had lower annual production.

The largest and oldest individuals generated the most important part of the production of the Mytilus 


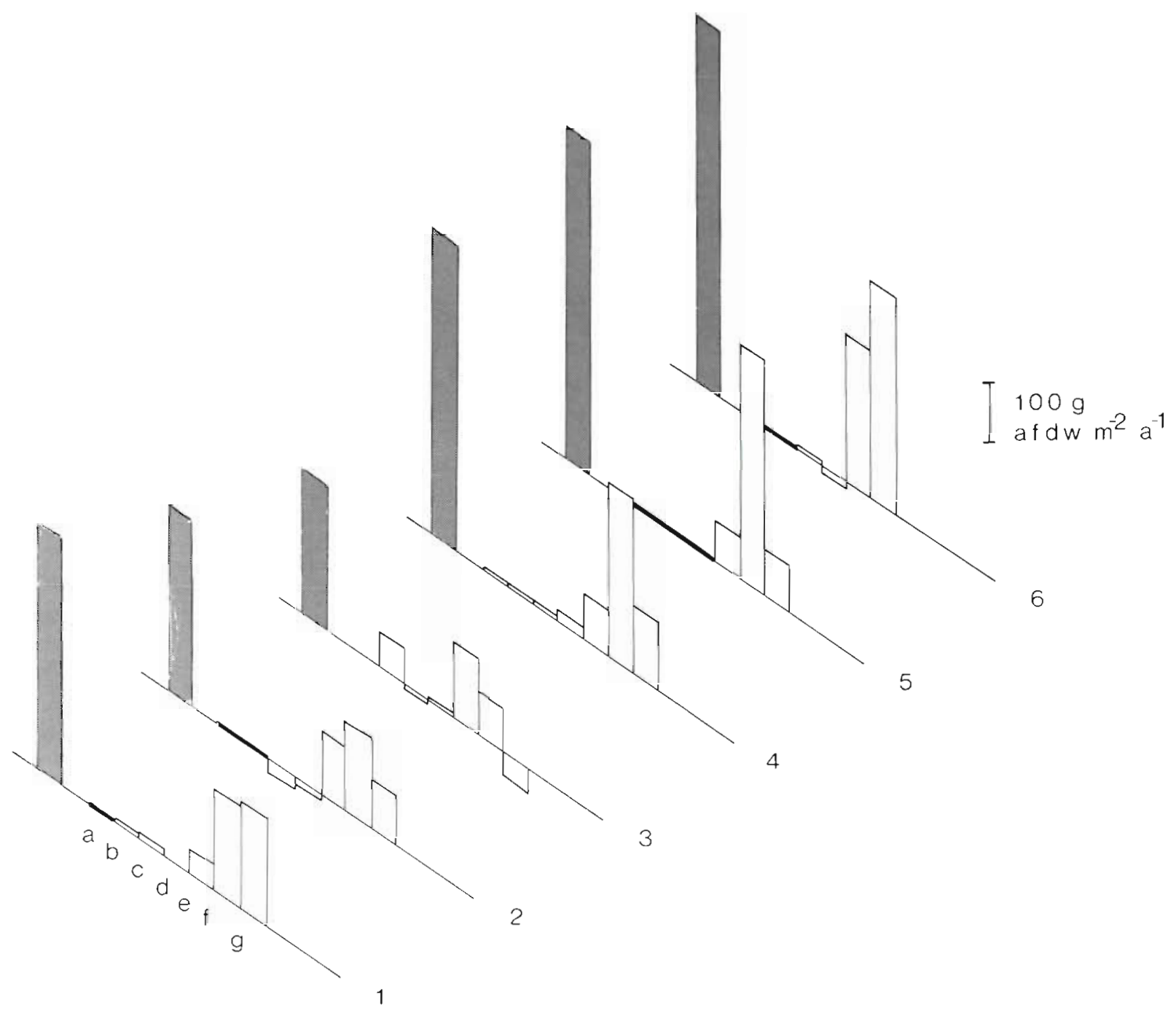

Fig. 5. Mytilus edulis. Mean annual production (g AFDW $\mathrm{m}^{-2} \mathrm{yT}^{-1}$ ) (shaded column) and annual production of size classes (a to g) at Sites 1 to 6

edulis population as a result of their dominant biomass in Königshafen in 1984 (Fig. 5). Therefore the P/B ratio of the population was distinctly lower than 1 at all sites investigated. The $\mathrm{P} / \mathrm{B}$ ratio of the older cohorts decreased to 0.2 whereas the $\mathrm{P} / \mathrm{B}$ ratios of the younger cohorts lay between 1 and 2 .

Miean monthly production was highest from June to August (Fig. 4A) representing $48 \%$ of annual production. The lowest monthly production was measured during the spawning season in April and May when mussels lost a considerable part of their body weight. These losses were as high as $37 \%$ of net annual production. This means that a large amount of material produced by the mussels is removed from the system. The energy spent by the mussels in this way is necessary to secure reproduction. On the other hand larvae and eggs of mussels enter the pelagic food chain and thus become important to another subsystem. The material lost due to overwintering metabolic require- ments was $12 \%$ of total net production in the very mild winter of $1983 / 84$

The maximum potential length $L_{x}$ of the mussels was $61.5 \mathrm{~mm}$ (Fig. 6). Comparing the mean shell length of the largest size cohort with the maximum potential size reveals that these older mussels had not attained their maximum size. The length growth rates, estimated from the Ford Walford plot (Fig. 6) were low ( $k=0.17$ to 0.30 ) compared to mussel beds dominated by younger mussels.

\section{Production of associated macrofauna}

The associated fauna produced $31 \mathrm{~g} \mathrm{AFDW} \mathrm{m}^{-2} \mathrm{yr}^{-1}$ (Table 3). This corresponds to only $7 \%$ of total annual community production in the mussel bed.

Benthic suspension-feeding animals, mainly barnacles, accounted for the largest share in this production 


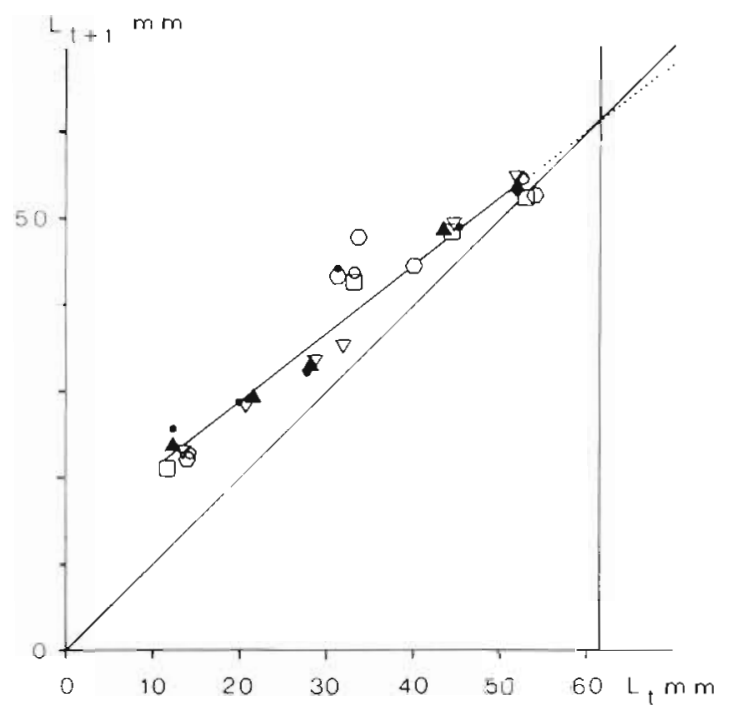

Fig. 6. Ford Walford plot of the Mytilus edulis population of Konigshafen. $L_{t}$ : mean shell length of different size classes at the beginning of the study; $L_{1+1}$ : mean shell length of different size classes at the end of 1984 . Symbols represent the 6 sites investigated (see Fig. 2): (0) Site 1, (a) Site 2, (0) Site 3, (4) Site 4 , ( $\bullet$ Site 5 , ( $)$ Site 6 . The regression line of best fit was $\mathrm{L}_{1+1}=13.14 \times 0.79 \mathrm{~L}_{1}, \mathrm{r}=0.98, \mathrm{n}=33$. The intersection of the regression line and the $45^{\circ}$ line represents a maximum potential size of $L_{x}=61.5 \mathrm{~mm}$

$(40 \%)$. Production of Semibalanus balanoides was low in winter and increased in spring and summer (Fig. $4 \mathrm{C}$ ). Production of the population was dominated by young barnacles. The production of this size class was very high in May, the month after settlement. Latersettled individuals exhibited lower production rates. The varying rates were a result of food supply. The high production of young barnacles coincided with the bloom of diatoms in May and August (R. Asmus unpubl.). Production of Balanus crenatus showed lower values in March and June than in other months (Fig. $4 \mathrm{D}$ ). The production of this population was due to one size class only and showed a slightly negative trend in abundance during the year investigated.

The part of grazers, mainly Littorina littorea, in the production of the associated fauna was similar to that of suspension feeders $(37 \%)$. L. littorea had a mean annual production of $10 \mathrm{~g} \mathrm{AFDW} \mathrm{m}^{-2} \mathrm{yr}^{-1}$ (Table 3). Young specimens showed negative production values from December to April, while this critical period was shorter for adults (February to April). The main part of production was formed in summer (June to August) (Fig. 4B). Afterwards production declined.

In contrast to grazers and suspension feeders, predators ( $16 \%$ of total production of associated macrofauna) and detritus feeders $(7 \%)$ were of lesser importance for the total production (Table 3 ).

\section{Size spectra of biomass and production}

The biomass size distribution demonstrates an enormous superiority of larger individuals over smaller size groups. The biomass over the total size range was thus increasing exponentially from lower to higher size classes.

The biomass of different trophic groups had strongly varying size distributions. The main portion of biomass of the investigated community was built up by suspension-feeding animals, which were found within a size range of individual weight from 1.78 to $0.0003 \mathrm{~g} \mathrm{AFDW}$ (Fig. 7). On a logarithmic scale biomass values of suspension feeders decreased from the highest to the lowest size class. In the upper size range between $0.1 \mathrm{~g}$ and $1.78 \mathrm{~g}$ AFDW the community biomass was represented only by suspension feeders. In the next lower size range between 0.1 and $0.01 \mathrm{~g}$ AFDW suspension feeders were also dominant.

Grazers showed a similar size distribution of biomass, but the range in this trophic group was only from 0.1 to $0.003 \mathrm{~g}$ AFDW. Predators occurring permanently in the mussel bed were found in the same size range as grazers showing maximum biomass at an individual weight of $0.01 \mathrm{~g} \mathrm{AFDW}$. The maximum biomass of detritus feeders was concentrated in the smaller size groups. Their size spectrum extended from 0.03 to $0.0002 \mathrm{~g} \mathrm{AFDW}$.

Although P/B ratios in small organisms are higher than in larger organisms, the production size spectrum is very similar to the biomass size spectrum (Fig. 8). The greatest production is likewise concentrated in the upper size classes and gradually decreases over the total range to small size classes.

\section{DISCUSSION}

\section{Biomass of Mytilus edulis}

The mean annual biomass of $1208 \mathrm{~g} \mathrm{AFDW} \mathrm{m}^{-2}$ of the Mytilus edulis population in the Königshafen area is comparable to the biomass values reported by Dare (1976), which were the highest values reported for natural mussel beds. Intertidal mussel beds are places of high macrofaunal density (Table 4). There are only few benthic communities with a similar dense aggregation of biomass to beds of blue mussels. In most cases the main component of those benthic communities also consists of suspension feeders. In intertidal waters, the biomass of cockle beds (Beukema 1982) and of dense aggregations of clams Mercenaria mercenaria (Walne 1972) represents only the lower range of biomass values reported from $M$. edulis beds. But biomass values of reefs of oysters Crassostrea virginica fall in the upper 


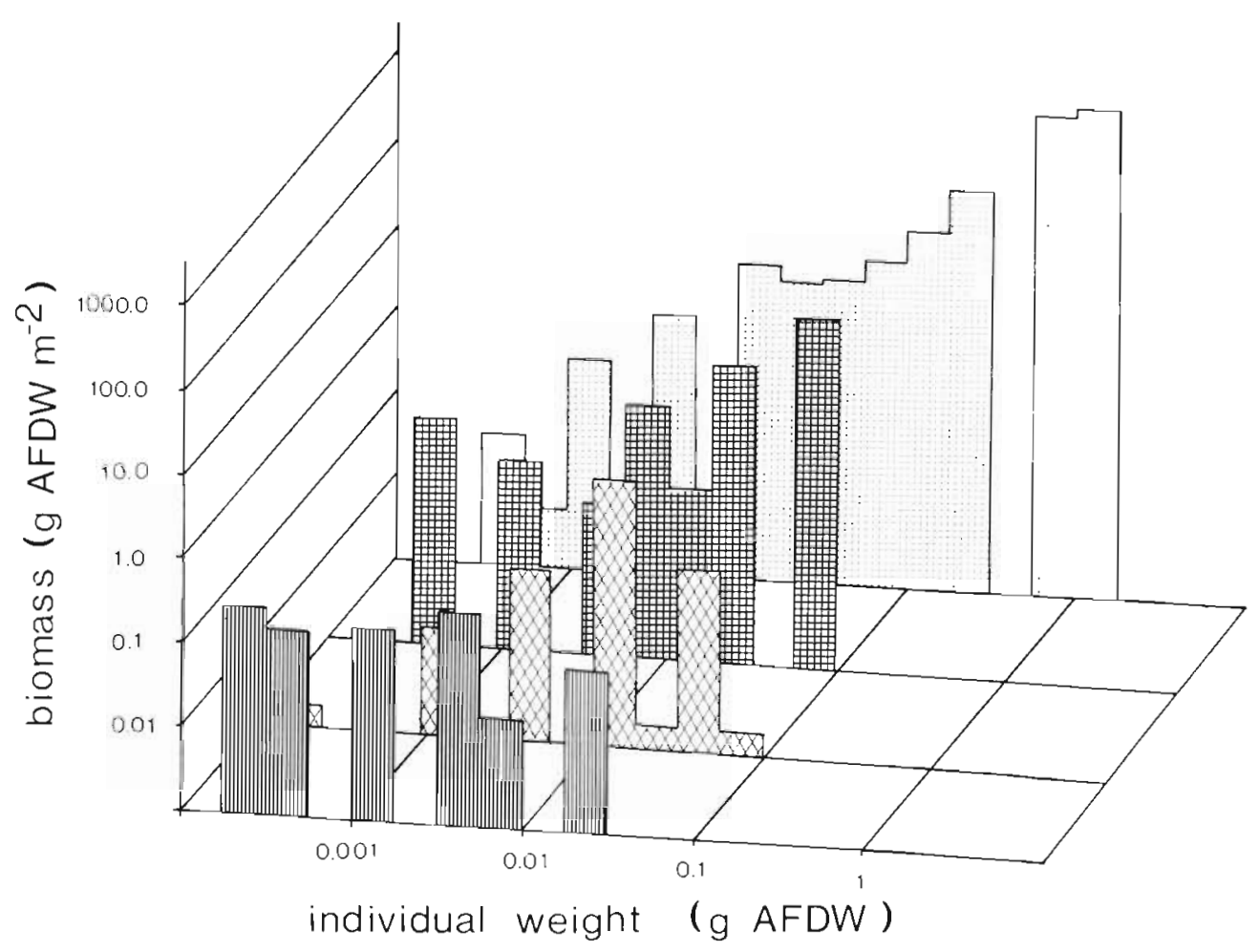

Fig. 7. Size spectra of mean annual biomass ( $g$ AFDW $\mathrm{m}^{-2}$ ) of different trophic groups of the mussel bed community. Dotted: suspension feeders; chequered: grazers; chequered diagonally: predators; vertically lined: detritus feeders

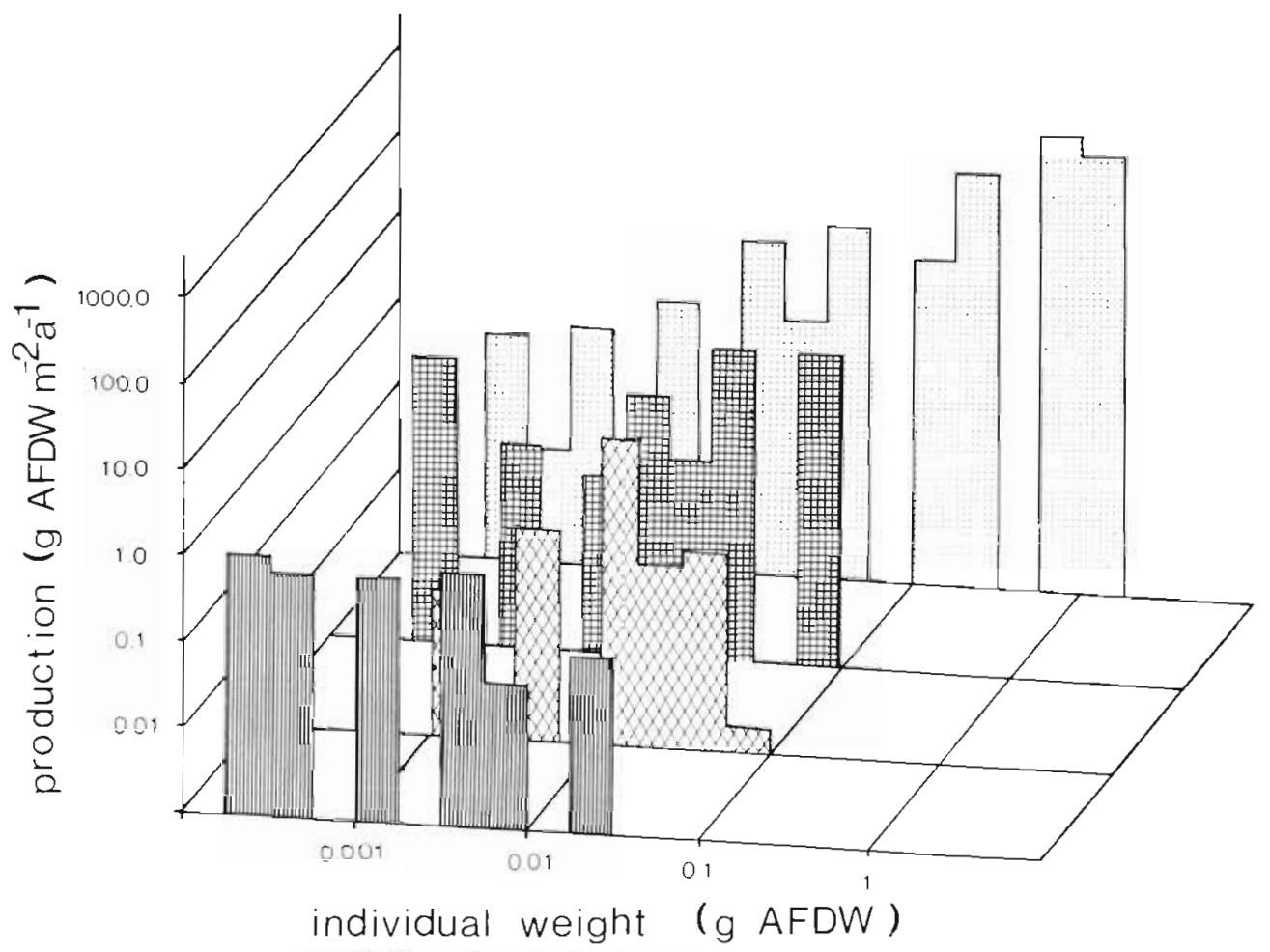

Fig. 8. Size spectra of annual production ig AFDW $m-y$, of difterent trophic groups of the mussel bed community. Dotted: suspension feeders; chequered: grazers; chequered diagonally: predators; vertically lined: detritus feeders 
Table 4. Mytilus edulis. Biomass of populations in different regions, expressed in AFDW. Original data of dry flesh weight, ashfree dry flesh weight and total live weight were multiplicated by factors $1.27,1.53$ and 0.09 respectively for calculating total ashfree dry weight

\begin{tabular}{|lcl|}
\hline Area & Biomass (g AFDW m ${ }^{-2}$ ) & Source \\
- Killary Harbour, Ireland, natural mussel beds & 106.2 & Rodhouse et al. 1985 \\
Askö area (total archipelago) & 20.2 & Kautsky 1981 \\
Mussel beds on hard bottom, Japan & 524.0 & Tsuchiya 1980 \\
Wadden Sea, intertidal Mytilus edulis outside dense beds & 6.2 & de Wilde \& Beukema 1984 \\
Wadden Sea, intertidal Mytilus edulis outside dense beds & $0.88-2.04$ & Beukema et al. 1978 \\
Morecombe Bay, England & 1742 & Dare 1976 \\
Ythan estuary, Scotland & $25-509$ & Milne \& Dunnet 1972 \\
Danish Wadden Sea & 712 & Theisen 1968 \\
\hline
\end{tabular}

range of biomass values of $M$. edulis beds (Dame 1976, Bahr 1976). The present biomass values are thus among the highest values for marine benthic communities or populations. Compared to the biomass range of tropical reef corals of $105 \mathrm{~g}$ to about $200 \mathrm{~g} \mathrm{AFDW} \mathrm{m}^{-2}$ (Odum \& Odum 1955, Lewis 1981), natural mussel beds show a distinctly higher standing stock. Even the biomass of various reef molluscs was far under the biomass range of M. edulis beds (Richard 1981).

Insufficient investigations have been made on the problem of an upper limit for density and mass of animal aggregations. Up to now it is unknown to what extent the range of such a carrying capacity can vary. Maximum biomass values of about $1.5 \mathrm{~kg}$ AFDW m $\mathrm{m}^{-2}$ led Dare (1976) to his suggestion that this value was approximately the carrying capacity of his area of investigation. Maximum biomass values of the present study range in the same order of magnitude 1.2 to $1.9 \mathrm{~kg} \mathrm{AFDW} \mathrm{m}^{-2}$ ). The development of such maximum standing stock values in general seems to depend on a sufficient food supply, which can only be met by a pelagic food source. Therefore the high food demand of a high standing stock can only be satisfied by energy transported by tides and currents. Thus such densely aggregated animal communities depend on the import and export situation of adjacent areas.

Where mussel beds of this study were covered with Fucus vesiculosus f. mytili their biomass (and presumably potential carrying capacity) was distinctly reduced. This is in contrast to the theory of Nienburg (1925), who described the association Fucus vesiculosus f. mytili with Mytilus edulis as a symbiosis between these 2 species, as a result of morphological characteristics of the $F$. vesiculosus f. mytili plants.

\section{Biomass of associated fauna}

The biomass of the associated fauna was found to be very similar to other intertidal benthic communities of the Wadden Sea (Asmus 1982, Asmus \& Asmus 1985,
Beukema 1974, 1976, 1982, Beukema et al. 1978) (Table 5). In Königshafen, 41 macrofauna species could be identified and, considering that some species occurred irregularly, the number of species is in the same order of magnitude as that found by Briggs (1982) in Lough Foyle (34 species). Up to now the quantitative aspect of the fauna associated with Mytilus edulis has hardly been investigated.

Although the production of faeces and pseudofaeces of mussels provides a rich food supply for detritusfeeding animals, the biomass of detritus feeders was far below all other trophic groups of the community and also less than biomass of detritus feeders of the adjacent areas (Table 5) (Asmus 1984, Asmus \& Asmus 1985). Oxygen deficiency and production of $\mathrm{H}_{2} \mathrm{~S}$ in the sediment under the mussel bed may be the main reason for a reduction of biomass of endofauna species. Similar observations were made in sediments under mussels cultured on hanging long lines. Under these cultures the original benthic fauna is replaced successively by opportunistic polychaetes which show fluctuations in abundance due to changes in the position of the redoxcline (Mattson \& Lindén 1983). Tenore et al. (1982) demonstrate that in a coastal embayment with little activity in culturing mussels a diverse infauna assemblage with high biomass occurs, whereas in an embayment with high activity of mussel culturing only a low biomass was found. Because in Tenore's investigation no oxygen deficiencies were measured in the bottom water, it follows that some other sediment property was unfavourable for infaunal life. In the present study anaerobic conditions of the sediment were obvious, and therefore the most probable reason for a low biomass of the infauna.

\section{Production of Mytilus edulis}

The Mytilus edulis population in this study shows a size spectrum with maximum abundance for the larger sized mussels. Previous studies on $M$. edulis also 
Table 5. Mean biomass and total annual production of the mussel bed compared to other intertidal communities in the Königshafen area and their trophic components (Asmus 1.984, Asmus \& Asmus 1985)

\begin{tabular}{|c|c|c|c|c|c|}
\hline \multirow[t]{2}{*}{ Community } & \multirow{2}{*}{$\begin{array}{l}\text { Total annual mean bio- } \\
\text { mass ( } \mathrm{g} \text { AFDW m }{ }^{-2} \text { ) }\end{array}$} & \multicolumn{4}{|c|}{ Annual mean biomass of trophic groups ( $g$ AFDW m ${ }^{-2}$ ) } \\
\hline & & Grazers & $\begin{array}{c}\text { Suspension } \\
\text { feeders }\end{array}$ & $\begin{array}{l}\text { Detritus } \\
\text { feeders }\end{array}$ & Predators \\
\hline Nereis-Corophium belt & 16.48 & 10.59 & 0.16 & 4.12 & 1.61 \\
\hline Seagrass bed & 30.17 & 21.20 & 0.74 & 7.92 & 0.31 \\
\hline Arenicola flat & 27.55 & 18.85 & 0.79 & 7.38 & 0.53 \\
\hline Mussel bed (this study) & $1243.15(34.68)^{\circ}$ & 21.22 & $1218.49(9.95)^{\bullet}$ & 1.07 & 2.44 \\
\hline Community & $\begin{array}{l}\text { Total annual production } \\
\qquad\left(\mathrm{g} \text { AFDW } \mathrm{m}^{-2} \mathrm{YI}^{-1}\right)\end{array}$ & \multicolumn{4}{|c|}{$\begin{array}{l}\text { Secondary production of trophic groups } \\
\qquad\left(\text { g AFDW } \mathrm{m}^{-2} \mathrm{yr}^{-1}\right)\end{array}$} \\
\hline Nereis-Corophium belt & 17.48 & 13.16 & 0.01 & 2.43 & 1.68 \\
\hline Seagrass bed & 48.22 & 38.85 & 1.29 & 7.63 & 0.45 \\
\hline Arenicola flat & 50.21 & 33.13 & 1.80 & 12.74 & 1.17 \\
\hline Mussel bed (this study) & $468.09(31.23)^{\circ}$ & 11.43 & $449.27(12.43)^{\circ}$ & 2.25 & 5.12 \\
\hline
\end{tabular}

recorded high secondary production (Table 6). Dare (1976) noted that production was highest in the first year after settlement and later decreased because of higher mortality. The low production measured by Rodhouse et al. (1985) and Milne \& Dunnet (1972) resulted from the dominance of older and larger mussels compared to the young population investigated by Dare (1976).

In this investigation $\mathrm{P} / \mathrm{B}$ ratios of Mytilus edulis varied due to different proportions of size classes in the population. Individuals of the smallest size showed $P / B$ ratios between 1 and 2 whereas the older individuals ( 4 to $5 \mathrm{yr}$ old) were characterized by low values of 0.2 . Because older mussels with low $\mathrm{P} / \mathrm{B}$ ratios predominate, the $\mathrm{P} / \mathrm{B}$ ratio of the whole population is 0.36 . Bayne \& Worrall (1980) showed that individual production of $M$. edulis from 2 populations was very variable, especially due to year classes. $\mathrm{P} / \mathrm{B}$ ratios of young mussels are up to tenfold higher than older ones. Literature values for annual $\mathrm{P} / \mathrm{B}$ ratios present a wide range from 0.10 for older specimens (Bayne \& Worrall 1980) to 3.4 for individuals just settled (Dare 1976). Allometric $\mathrm{P} / \mathrm{B}$ scaling is often used for estimation of secondary production. Reasonable estimates of production and its distribution among size groups are found using this method in natural communities (Schwinghamer et al. 1986). Banse \& Mosher (1980) propose a relation between the annual $\mathrm{P} / \mathrm{B}$ value and the mass of an individual during maturation, which is suggested to be valid over a wide range of animal species. Because $M$. edulis matures early (i.e. at a size of 15 to $20 \mathrm{~mm}$ or $0.04 \mathrm{~g}$ AFDW) (Suchanek 1981), the P/B value, estimated following Banse's $P / B$ mass ratio, is 3.4 . This $P / B$ ratio is equivalent only to that of very young mussels, and overestimates the $\mathrm{P} / \mathrm{B}$ ratio for larger mussels. In contrast, the P/B mass ratio of Banse \& Mosher (1980) is very useful for calculations of production, if the mass at maturity is similar to the mean individual weight of the population studied or if the biomass of the population is so low that errors in measuring production would be greater than errors from usage of the mass $\mathrm{P} / \mathrm{B}$ equation. For populations with a wide size range like $M$. edulis this equation has to be used with care. Another equation, which correlates $\mathrm{P} / \mathrm{B}$ ratio and life span (Robertson 1979), gives an annual P/B ratio of 0.86 . This is in good agreement with mean values of the empirical data range for $M$. edulis up to now. For the dominant parts of a community showing in most cases a wide size range, it is not possible to consider a $\mathrm{P} / \mathrm{B}$ ratio as a constant factor in the calculation of production because $\mathrm{P} / \mathrm{B}$ ratios show a great variability and are dependent upon the different growth conditions and age structure of the population. $A$ P/B ratio however is a useful index for characterizing the conditions for production in a population.

\section{Production of associated macrofauna}

Until now no study has been made dealing with the production of the total faunal assemblage of a mussel bed. Production of the fauna associated with Mytilus edulis was found to be $31 \mathrm{~g}$ AFDW m $\mathrm{m}^{-2} \mathrm{yr}^{-1}$. This production is dominated by filter feeders; especially barnacles. Benthic grazers also are very important for the production. Herbivorous forms represent threequarters of the production of the non-Mytilus macrofauna. The production of predators is only $16 \%$ of the total non-Mytilus macrofauna. The percentage of production of detritus feeders is even lower. The associ- 
Table 6. Production of Mytilus edulis and other species in natural mussel beds. Conversion factors for calculating AFDW are given in Table 4

\begin{tabular}{|lccc|}
\hline & Production $\left(\mathrm{g} \mathrm{AFDW} \mathrm{m}{ }^{-2} \mathrm{yr}^{-1}\right)$ & P/B & Source \\
\hline Killary Harbour, Ireland & 106.0 & 1 & Rodhouse et al. 1985 \\
Lynher and Tamar esturay, England & $0.3-1.2$ & $0.1-2.4$ & Bayne \& Worrall 1980 \\
& (per individual mussel) & Dare 1976 \\
Morecombe Bay, England & $2150-3850$ & $1.4-2.1$ & Milne \& Dunnet 1972 \\
Ythan esturay, Scotland & $570-1500$ & $1.1-3.4$ & Bahr 1976 \\
Crassostrea reef & 343 & 0.7 & Dame 1976 \\
Crassostrea Georgia & 200 & $1.2^{*}$ & Hibbert 1976 \\
Crassostrea South Carolina & & 1.2 & \\
Mixed bivalve community England & 226 & & \\
P/B ratios calculated from original data & & & \\
\hline
\end{tabular}

ated fauna of mussel beds shows a higher $\mathrm{P} / \mathrm{B}$ ratio than the mussels themselves. But in spite of intense production no biomass increase could be found over the year. Thus we can assume the turnover of the associated macrofauna assemblage as well as the turnover of small mussels was more rapid than that of the adult mussel population.

\section{Size spectra of biomass and production}

The size distributions of biomass and production of the different trophic groups of the community show similar patterns. Large suspension feeders are the main producers. Because of their size these suspension feeders are not utilized by most of the predator species.

Carcinus maenas is the main invertebrate predator in the mussel beds of Königshafen. Direct feeding on Mytilus edulis is often observed (Scherer \& Reise 1981). In cage experiments 3 size groups of mussels were fed to C. maenas (up to $57 \mathrm{~mm}$ carapace width; Ebling et al. 1964). Mussels of the largest group (>45 $\mathrm{mm}$ ) were almost spared, from the medium sized group (25 to $37 \mathrm{~mm}$ ) only very few mussels were taken, whereas in the smallest group $(<21 \mathrm{~mm})$ the most intense feeding was observed. The impact of other predators found in this community is mainly on the associated fauna. Migrating predators also have a strong influence on intertidal benthic communities (Arntz 1978, Menge 1976, 1983, Paine 1971, Reise 1978) but their significance in mussel beds has not yet been studied. The size spectra of mussels preferred by fishes is also unknown, but it is possible that fishes also feed more intensively on the associated fauna than on large mussels.

It is often demonstrated that the main part of the production of a mussel population is consumed by birds (Belopolskii 1961, Kautsky 1981, Swennen 1976). Mussels are the main food for eiders, long-tailed ducks, common scoters and goldeneyes which visit the Wadden Sea especially in winter (Swennen 1976, Voous 1962). During low water oystercatchers and gulls feed on mussels and their associated fauna (Milne \& Dunnet 1972). Birds were found to consume most of the production of the Mytilus edulis population (Milne \& Dunnet 1972, Craeymeersch et al. 1986).

In contrast, where rapid growth of the population leads to physical instability of the mussel bed, much of the organic production of the mussel population is dissipated to decomposers and detrital food chains (Dare 1976). The mussel population of Königshafen is characterized by low biomass and production in the important prey class. But the predation impact on Mytilus edulis of this size class may be lowered because the production of the associated fauna is also available and thus reduces the demand on mussels. This may be a kind of buffering effect on mussel predation. The production of the larger size classes is stored in animal tissue, used for reproduction or for metabolism during low food supply. This is important in the functioning of the ecosystem, especially the nutrient budget and the import and export of food to and from the adjacent communities of the whole intertidal flat.

\section{Production rank curve}

The production rank curve of the community (Fig. 9) is similar to those found by Warwick (1982) for a sublittoral Modiolus modiolus community dominated by suspension feeders. Warwick (1982) found that such a distribution typical for suspension-feeding communities is in contrast to that typical for a depositfeeder community. Warwick's production rank curves are based on the percentages of total production by single species. Thus these rank curves are independent of the absolute value. The percentage of the lower 


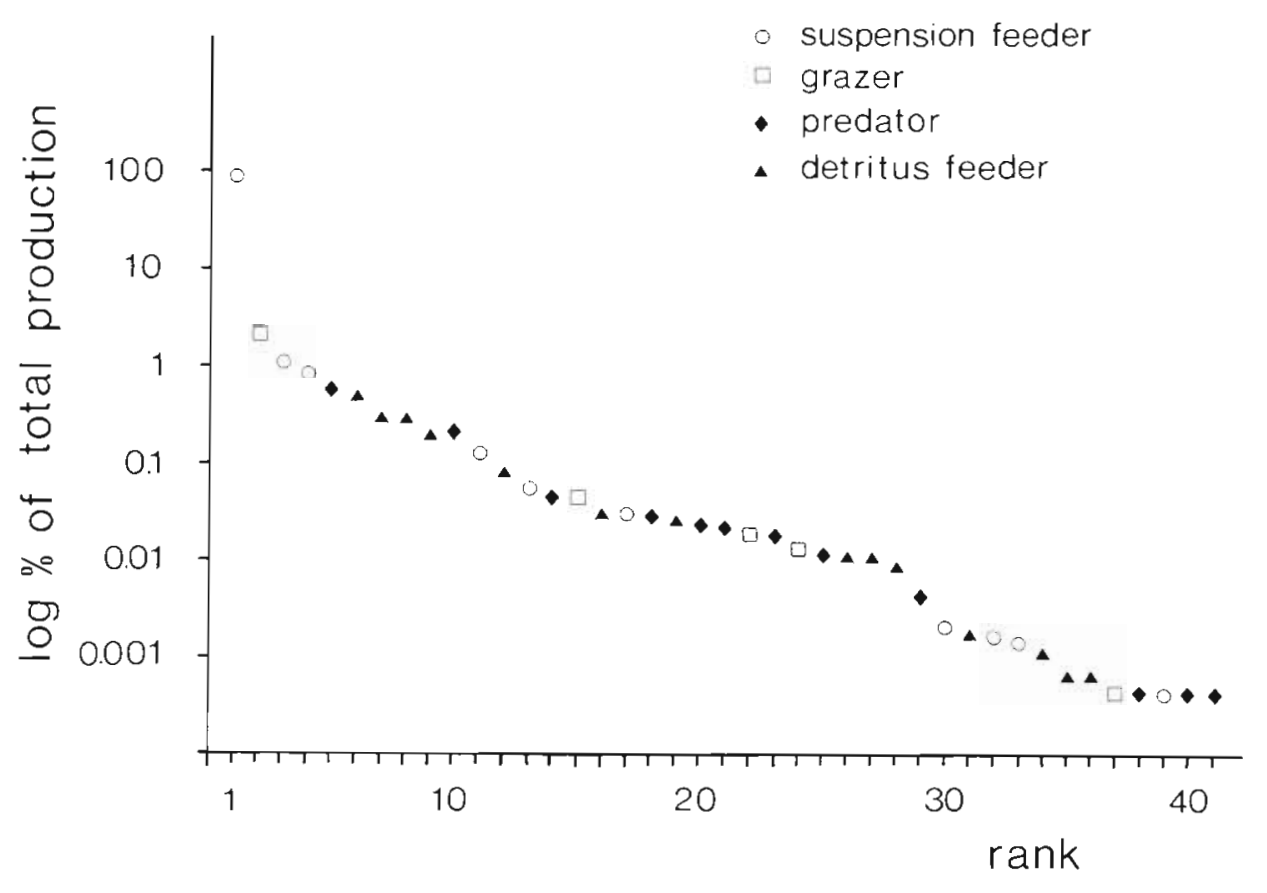

Fig. 9. Production rank curve ( $\log \%$ of total production) for a Mytilus edulis community. Symbols show different trophic levels ranked species seems to be negligible, but actually the production of these species is just as high as in a mixed community and shows per se similar relationships between the proportions of the production of species. Although the main part of community production is concentrated in Mytilus edulis, production of the associated fauna is within the same range as the community production of other intertidal areas. The dominating species has no competitive effect on the production of the associated fauna. Mussel beds contrast to intertidal sand bottom communities in that the species composition is different and the main share of biomass and production of the community is shifted to the epibenthos (Asmus \& Asmus 1985)

\section{CONCLUSIONS}

\section{Role of mussel bed community in intertidal ecosystem}

The biomass of the investigated mussel bed is in the range of the highest values found in studies of other marine benthic communities. Although the low P/B ratio suggests that the optimum of growth conditions has been exceeded, the production of the community is high. The main productive potential is developed by larger size classes which are 'only of minimal importance for predation. Therefore the community can be divided into 2 functional compartments (Fig 10): One is a 'storage compartment', with a great productive potential leading to a further increase in biomass or being spent for metabolic and reproductive require- ments. The energy demand of this compartment is higher than the community habitat can afford, so that it needs auxiliary energy from outside. This compartment governs import and export of nutrients as well as oxygen and forms the chemical and physical conditions for the community. The other compartment, the 'turnover compartment', is of relative low biomass and production. The $\mathrm{P} / \mathrm{B}$ ratios in this group are high and indicate a higher turnover than in the 'storage compartment'. The role of the mussel bed as a feeding area is concentrated in this functional group, because the productive potential is available mainly to predators. Because young mussels are also members of this 'turnover compartment', the buffering effect of the associated macrofauna on predation may be important for young mussels to succeed in growing up to the storage compartment. So despite their relative low biomass and production the associated macrofauna has a key function in the development of intertidal mussel beds which have an important impact on the whole tidal flat ecosystem.

Acknowledgements. Thanks are due to Dr K. Reise for his interest and helpful discussions and to Mrs. G. Kredel and my wife for kindly revising the English text. A grant was awarded by the Deutsche Forschungsgemeinschaft (As 49/1-1; Re 425/ $6-1)$.

\section{LITERATURE CITED}

Arntz, W. E. (1978). The 'upper part' of the benthic food web: the role of macrobenthos in the western Baltic. Rapp. P.-v. Réun. Cons. int. Explor. Mer 173: 85-100

Asmus, H. (1982). Field measurements on respiration and secondary production of a benthic community in the north 


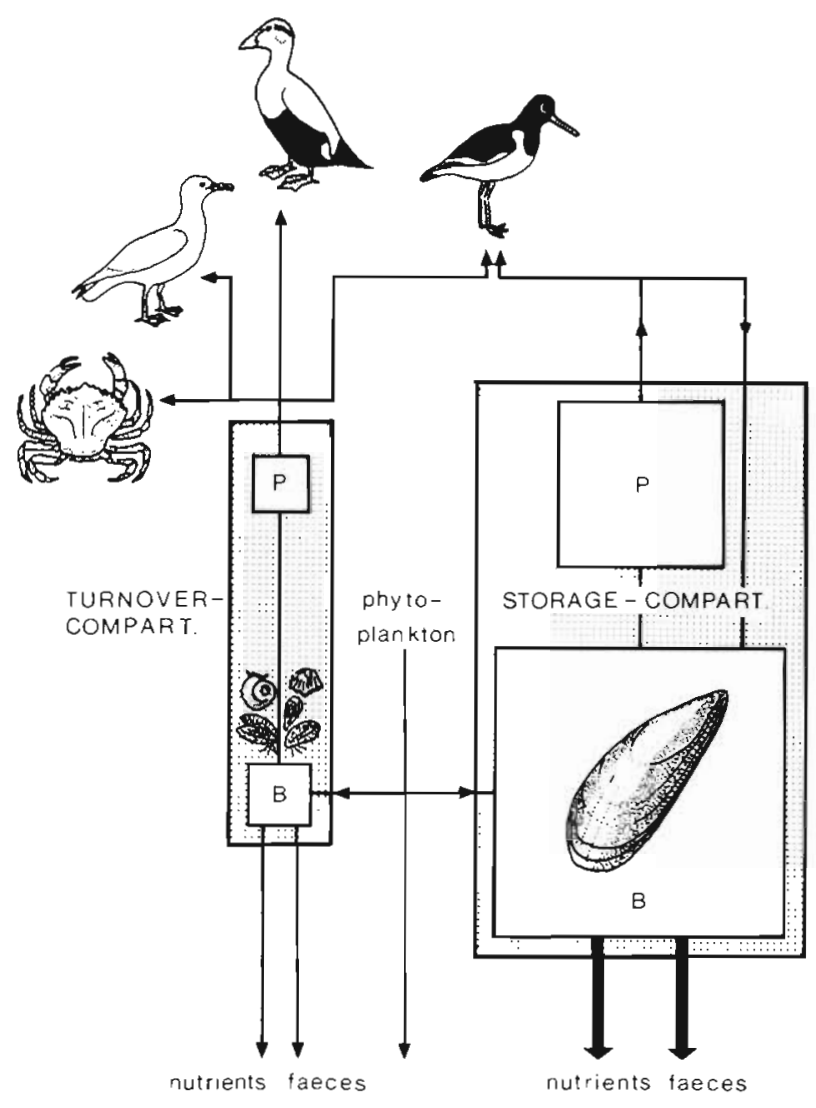

Fig. 10. Simplified model of the partitioning of production of an intertidal mussel bed, showing storage and turnover compartments and their availability to predators. The boundary between these 2 compartments is drawn at an individual weight of $0.1 \mathrm{~g}$ AFDW $B$ is the mean biomass (turnover compartment: $49.75 \mathrm{~g}$ AFDW $\mathrm{m}^{-2}$; storage compartment: $1193.40 \mathrm{~g} \mathrm{AFDW} \mathrm{m}^{-2}$ ); $\mathrm{P}$ is annual production (turnover compartment: $42.30 \mathrm{~g}$ AFDW $\mathrm{m}^{-2} \mathrm{yr}^{-1}$, storage compartment: $425.80 \mathrm{~g} \mathrm{AFDW} \mathrm{m}^{-2} \mathrm{yr}^{-1}$ ). P/B ratio is 0.85 for the turnover compartment and 0.36 for the storage compartment

ern Wadden Sea. Neth. J. Sea Res. 16: 403-413

Asmus, H. (1984). Freilanduntersuchungen zur Sekundärproduktion und Respiration benthischer Gemeinschaften im Wattenmeer der Nordsee. Ber. Inst. Meeresk. Univ. Kiel 122: $1-171$

Asmus, H., Asmus, R. (1985). The importance of grazing food chain for energy flow and production in three intertidal sand bottom communities of the northern Wadden Sea. Helgoländer Meeresunters. 39: 273-301

Bahr, L. M., Jr. (1976). Energetic aspects of the intertidal oyster reef community at Sapelo Island, Georgia, USA. Ecology 57: 121-131

Banse, K., Mosher, S. (1980). Adult body mass and annual production/biomass relationships of field populations. Ecol. Monogr. 50 (3): 355-379

Bayne, B. L., Worrall, C. M. (1980). Growth and production of mussels Mytilus edulis from two populations. Mar Ecol. Prog. Ser. 3: 317-328

Belopolskii, L. O. (1961). Ecology of the sea colony birds of the Barent Sea. H. A. Humphrey, London
Beukema, J. J. (1974). Seasonal changes in the biomass of the macrobenthos of a tidal flat in the Dutch Wadden Sea. Neth. J. Sea Res. 8: 94-107

Beukema, J. J. (1976). Biomass and species richness of the macrobenthic animals living on the tidal flats of the Dutch Wadden Sea. Neth. J. Sea Res. 10: 236-261

Beukema, J. J. (1982). Annual varaition in reproductive success and biomass of the major macrozoobenthic species living in a tidal flat area of the Wadden Sea. Neth. J. Sea Res. 16: $37-45$

Beukema, J. J., de Bruin, W., Jansen, J. J. M. (1978). Biomass and species richness of the macrobenthic animals living in the tidal flats of the Dutch Wadden Sea: long term changes during a period with mild winters. Neth. J. Sea Res. 13 (2): 203-223

Briggs, R. P. (1982). Community structure and growth of Mytilus edulis L. in Lough Foyle. Proc. R. Ir. Acad. 82; 245-259

Craeymeersch, J. A., Herman, P. M. J., Meire, P. M. (1986). Secondary production of an intertidal mussel (Mytilus edulis L.) population in the Eastern Scheldt (sw. Netherlands). Hydrobiologia 153: 107-115

Dame, R. F. (1976). Energy flow in an intertidal oyster population. Estuar. coast. mar. Sci. 4 (3): 243-253

Dare, P. J. (1976). Settlement, growth and production of the mussel, Mytilus edulis L., in Morecambe Bay, England. Fishery Invest., Lond. II, 28 (1): 1-25

Ebling, F. J., Kitching, J. A., Muntz, L., Taylor, C. M. (1964). Ecology of Lough Ine. Part 1. Mytilus edulis. J. Anim. Ecol. 33: $73-82$

Hibbert, C. J. (1976). Biomass and production of a bivalve community on an intertidal mud flat. J. exp. mar. Biol. Ecol. 25 (3): $249-261$

Kautsky, N. (1981). On the trophic role of the blue mussel (Mytilus edulis) in a Baltic coastal ecosystem and the fate of the organic matter produced by the mussels. Kieler Meeresforsch. (Sonderh.) 5: 454-461

Lewis, J. B. (1981). Estimates of secondary production of reef corals. Proc. 4th Int. Coral Reef Symp., Manila, Vol. 2: 369-374

Mattson, J., Lindén, O. (1983). Benthic macrofauna succession under mussels Mytiluis edulis L. (Bivalvia), cultured on hanging long lines. Sarsia 68: 97-102

Menge, B. A. (1976). Organization of the New England rocky intertidal community: role of predation, competition and environmental heterogeneity. Ecol. Monogr 46: 355-393

Menge, B. A. (1983). Components of predation intensity in the low zone of the New England rocky intertidal region. Oecologia (Berl.) 58: 141-155

Milne, H., Dunnet, G. M. (1972). Standing crop, productivity and trophic relations of the fauna of the Ythan estuary. In: Barnes, R. S. K., Green, J. (ed.) The estuarine environment. Applied Science Publ., London, p. 56-196

Nienburg, W. (1925). Eine eigenartige Lebensgemeinschaft zwischen Fucus und Mytilus. Ber. dt. bot. Ges. 43: 292-298

Odum, H. T., Odum, E. P. (1955). Trophic structure and productivity of a windward coral reef community on Eniwetok Atoll. Ecol. Monogr. 25: 291-320

Paine, R. T. (1971). A short term experimental investigation of resource partitioning in a New Zealand rocky intertidal habitat. Ecology 52: 1096-1106

Reise, K. (1978). Experiments on epibenthic predation in the Wadden Sea. Helgoländer wiss. Meeresunters. 31: 55-101

Richard, G. (1981). A first evaluation of the findings on the growth and production of the lagoon and reef molluscs in French Polynesia. Proc. 4th Int. Coral Reef Symp., Manila, Vol. 2: $637-641$ 
Robertson, A. I. (1979). The relationship between annual production: biomass ratios and lifespans for marine macrobenthos. Oecologia (Berl.) 38: 193-202

Rodhouse, P. G., Roden, C. M., Hensey, M. P., Ryan, T. H. (1985). Production of mussels Mytilus edulis in suspended culture and estimates of carbon and nitrogen flow: Killary Harbour, Ireland. J. mar. biol. Ass. U. K. 65: 55-68

Scherer, B., Reise, K. (1981). Significant predation on microand macrobenthos by the crab Carcinus maenas $\mathrm{L}$. in the Wadden Sea. Kieler Meeresforsch. (Sonderh.) 5: 490-500

Schwinghamer, P., Hargrave, B., Peere, D., Hawkins, C. M. (1986). Partitioning of production and respiration among size groups of organisms in an intertidal benthic community. Mar. Ecol. Prog. Ser. 31. 131-142

Smaal, A. C., Verhagen, J. H. C., Coosen, J., Haas, H. A. (1986). Interaction between seston quantity and quality and benthic suspension feeders in the Oosterschelde, The Netherlands. Ophelia 26: 385-399

Suchanek, T. H. (1981). The role of disturbance in the evolution of life history strategies in the intertidal mussels Mytilus edulis and Mytilus californianus. Oecologia (Berl.) 50: $143-152$

Swennen, C. (1976). Populatie-structur en voedsel van de Eidereend Somateria mollissima L. in de Nederlandse Waddenzee. Ardea 64: 311-371

Tenore, K. R., Boyer, L. F., Cal, R. M., Corral, J., Garcia-
Fernandez, C., Gonzalez, N., Gonzalez-Gurriaran, E., Hanson, R. B., Iglesias, I., Krom, M., Lopez-Jamar, E., McClain, J., Pamatmat, M. M., Perez, A., Rhoads, D. C., de Santiago, G., Tietjen, J., Westrich, J., Windom, H. L. (1982). Coastal upwelling in the Rias Bajas. NW Spain: contrasting the benthic regimes of the Rias de Arosa and de Muros. J. mar. Res. 40: 701-772

Theisen, B. F. (1968). Growth and mortality of culture mussels in the Danush Wadden Sea. Meddr Danm. Fisk.-og Havunders., N. S. 6: $47-78$

Tsuchiya, M. (1980). Biodeposit production by the mussel Mytilus edulis L. on rocky shores. J. exp. mar. Biol. Ecol. 47: $203-222$

Voous, K. H. (1962). Die Vogelwelt Europas und ihre Verbreitung. Paul Parey, Hamburg

Walne, P. R. (1972). The importance of estuaries to commercial fisheries. In: Barnes, R. S. K., Green, J. (ed.) The estuarine environment. Applied Science Publ., London, p. 56-196

Warwick, R. M. (1982). The partitioning of secondary production among species in benthic communities. Neth. J. Sea Res. 16: 1-16

De Wilde, P. A. W. J., Beukema, J. J. (1984). The role of zoobenthos in the consumption of organic matter in the Dutch Wadden Sea. Neth. J. Sea Res. 10: 145-148

Winberg, G. G. (ed.) (1971). Methods for estimation of production of aquatic animals. Academic Press, London 